\title{
Postmodernity, Globalisation and Nationalist Conflict in the Former Yugoslavia
}

\author{
ADRIAN KAVANAGH
}

During the $1990 \mathrm{~s}$, several of the conflicts that have demanded most media attention have been associated with the disintegration of the Yugoslav Federation. A number of attempts have been made to outline the main causes of these, but these causal factors remain difficult to describe definitively, largely owing to the complexity of the postYugoslav political landscape. This paper studies the validity of employing a postmodern paradigm for investigating the conflicts in former Yugoslavia, as well as other current conflicts, arguing that the present cultural and philosophical context has to be addressed. After an outline of some of the key aspects of postmodernity, the focus centres on the importance of the media and the postmodern perspective on the issue of the nation state. Key theories related to postmodern conflict, with relation to economic and cultural factors, are outlined. These are evaluated as regards their applicability to the Yugoslav conflicts and - by extension - to all future wars in the postmodern era.

\section{Introduction}

Up to the events associated with the fall of the Eastern European Communist regimes in 1989, the continent of Europe had, since the end of World War II, remained free of major conflict. Most of Eastern Europe has made the political transformation to Western style democracy in a peaceful manner. However the same could not be said for the former Yugoslavia, which has proven to be the only part of the continent, excluding the former Soviet Union, to be gripped by extensive bloody conflicts. A number of different, yet interrelated, wars erupted there in the 1990s, the causes of which are many and complex.

This paper analyses the Yugoslav conflicts in terms of the cultural context in which these took place, namely that of a postmodern and increasingly globalising world. To root this discussion, this paper will commence with an outline of the main economic, societal and cultural

\footnotetext{
Adrian Kavanagh is Salesian of Don Bosco, from Co. Laois in the Republic of Ireland. He is in the first year of doctoral research in the Department of Geography at the National University of Ireland, where he is working on the topic 'Social Exclusion, Political Alienation and Methods of Community Empowerment'. This will aim to utilise a political geographical framework to study problems of social and economic inequalities.
} 
developments of the late twentieth century that can be associated with the twin processes of postmodernity and globalisation. As a means towards constructing a postmodern framework of conflict, two key elements of these processes, namely the importance of the media and the declining role of the nation state, shall be focused on and related in turn to the Yugoslav conflicts. Finally the key strands in postmodern theories of conflict shall be outlined, discussed, and analysed as regards their efficacy for explaining the recent wars in the Balkans.

\section{Postmodernity and Globalisation}

While difficult to exactly describe, as it contains many apparently contradictory elements, postmodernity can perhaps be best defined simply as the period subsequent to that of modernity. Indeed in some cases postmodern aspects have developed as a reaction to contentious elements in modernity. For instance, concerned with modernity's canonisation of progress, science and technology, postmodernity has pointed to the continuance of war, famine and environmental catastrophe in the modern era as reasons to view such views with suspicion. Postmodernists, moreover, dismissing notions of absolute truth in favour of relativism, have also discounted the modernist concept of the metanarratives. This is on the basis that they involve a form of bogus scientificity, demand a high degree of centralisation and social engineering, and run the risk of resulting in horrific excesses, such as the Holocaust or religious persecutions, when they are most 'efficiently' implemented.

If modernity has been perceived as the cultural logic of industrial capitalism, then the development of advanced or flexible capitalism is key to postmodernity. This involves a Post-Fordist economy, in which advances in technology, transport and capital fluidity have led to a decreased dependence on plant and fixed capital, a heterogeneity of branch-plant economies, and an increased reliance on information technology. Indeed, information has arguably emerged as the most important commodity in postmodern society. Most of the recent economic growth in the advanced economies has been linked to innovations in associated technologies. Using the terminology of Kondratieff's wave theory, information based technologies can be envisaged as the technological innovation powering the current upward phase of the Kondratieff wave. Some commentators, moreover, argue that information has become so important a commodity that future conflicts could erupt simply on the basis of attaining access to it. The fact that most information-based economic growth appears to benefit the highly educated and those with access to the new technologies, at the expense of the socially and economically marginalised, is a cause of 
concern. Many industrial workers have been cast into long-term unemployment because of new labour-saving technology, leading Arruda to refer to the current wave of economic growth as 'jobless growth'.' Such growth proves a means of maintaining, or even intensifying, current gaps in well-being between the core and peripheral regions.

Another aspect of postmodernity that requires attention is its upholding of a tolerance for, and growing interest in, ethnic diversity. This has involved giving a voice to ethnic minorities who previously had not been allowed a voice during the period of modernity. Despite this, an outbreak of, or intensification in, violent inter-ethnic conflict in diverse regions of the world has marked the postmodern era. This is perhaps one of the key paradoxes in postmodernity, in that the potential it offers for greater ethnic harmony and interaction often coexists simultaneously with increases in ethnically motivated hatred and violence. Often, sadly, postmodern influence in this area can extend no further than widening the variety of food types available to people, for, as Fukuyama notes, many simply perceive cultural diversity as involving 'a great choice among Chinese, Italian, Greek, Thai, or Mexican restaurants'.2 Hence the racist thug attacking Chinese immigrants can minutes later be eating a Chinese takeaway; the irony of which is lost on him.

Another aspect of postmodernity that demands some regard here is its treatment of Fukuyama's concept of the 'end of history'. In his famous essay, 'The End of History?', Fukuyama claimed that the decline of the Communist regimes in Eastern Europe had spelt the triumph of liberal democratic capitalism over Communism. ${ }^{3}$ This, in effect, spelt the "end of history' in that it also marked the end of all alternative political and economic systems to liberal capitalism. Certain postmodernists have attacked his ideas: the main problem for them being Fukuyama's apparent denial of the existence of 'other histories', such as those of Islam or the Third World. Glenny has, by contrast to Fukuyama, conceived of the Eastern European revolutions as amounting to a 'rebirth of history'.4 Moreover, as the 1990s have seen a considerable redrawing of the Eastern European political map, one could claim that the 'end of history' spells the 'time of geography'!

Postmodernity itself proposes the 'end of history' in that it disputes the modernist notion that history can be shaped by humans so as to achieve certain aims or dreams. Instead it prefers to cultivate a sense of immediacy where there are no real past or future and no big goals. This translates itself into a view of history known as nostalgia. With such a view of history, the context and cultural concerns of the present drive all representations of the past, and myth and historical stereotyping often prove of more 'value' than factual details about the past. It is hardly surprising, in such a context, that 
the Greater Serbia project of the Milosevic regime would achieve so much support from ordinary Serbs, fuelled as it was by the culturally intoxicating combination of the Kosovo myth and historical remembrance.

Like postmodernity, globalisation too has been the source of serious debate in the past decade. While it proves difficult to provide an exact definition of what it entails, in this paper globalisation will be described as a process involving a greater interdependence and interconnectivity between the different parts of the globe. This is a process that impacts on politics, economies and culture, and has been permitted by recent advances in the fields of transport, communications and information technology. ${ }^{5}$ Globalisation can be seen as another form of neo-colonialism in which national economies become increasingly integrated into, and dominated by, the activities of transnational corporations and global financial agencies, such as the IMF and the World Bank. This has a spatial element in that the actions of these bodies have increased the experience of poverty in the more impoverished regions of the globe. This has peripheralised them further, leading to what Kellner called an 'exponential growth' in the gaps in economic well-being on a regional, national and global scale. ${ }^{6}$

\section{The Media and Conflict}

Amongst the forces that shape opinions and culture in our postmodern world, it is undoubtedly the agents of the global media that hold most sway, especially television. This is due to the decline of print media in favour of more instantaneous forms continuing into the postmodern era, and underpinned by Baudrillard's conception of the visual image being the allpowerful element of postmodern culture. The power of television in our contemporary culture is undeniable. It has progressed to such an extent that Coleman has argued that all forms of public discourse, such as politics, education and religion, must change in nature considerably so as to be in a position to respond adequately to the demands of television. ${ }^{7}$ Hence it is very important to consider who controls television. Some television stations are state run, and hence they are likely to reflect, to some extent, the values and concerns of the governments who provide their finances, no matter how independent a brief they may have. Other stations are controlled, directly or indirectly, by global multimedia corporations and, as such, will always be portraying values and concerns that parallel those of economic, societal and cultural globalisation.

In terms of its impact on postmodern conflict scenarios, it can be argued that television can have a positive role to play in terms of bringing atrocities and crisis situations to the attention of the watching 'global village'. This allows for the shaping of public opinion, so as to persuade various 
governments that political capital can be gained by an interventionist strategy in certain crises, as happened most recently with regard to Kosovo. Such a position was seen in the earlier stages of the Bosnian conflict. In 1992, as Bosnian Serb forces succeeded in taking nearly 75 per cent of its territory, verbal reports of atrocities linked to ethnic cleansing were emerging from these conquered territories. However, it was not until television pictures were broadcast by ITN from the Omarska detention camp in northern Bosnia that the attention of the world was focused on the humanitarian crisis. July 1995 saw the massacre of over 7,000 Muslims at Srebrenica, the largest scale mass murder in Europe since the end of the Second World War. This event,was portrayed on television solely by means of eyewitness reports and aerial photography of mass graves. Hence it did not have the same visual impact as the death of 37 people due to a mortar shell in Sarajevo on 28 August 1995, the horror of which was televised all over the world. It was in the wake of the Sarajevo incident rather than the genocide in Srebrenica that NATO attacks on the Bosnian Serbs were launched in the autumn of $1995 .^{8}$ It is hardly surprising, in this context, that television has been portrayed as playing a key role in determining the policy-making of the main Western powers during the Bosnian crisis. While this may be too bald an evaluation of television's role, there is some rationale for holding that television, and other media forms, can have some impact in spurring governments towards military involvement, although not perhaps to the extent envisaged by the 1997 Bond movie Tomorrow Never Dies. It could, of course, also be suggested that governments used television as a means of manipulating public opinion in favour of military interventions that would have taken place anyway.

However television can also have the impact of lessening the desire for involvement in a conflict situation. It can also be noted that it has at times played a role in either adding unnecessary complexity to, or oversimplifying, the analysis of the causal factors underlying conflict situations. Often such reporting has in part helped to legitimate the inactivity and apathy of the international community when faced with crises requiring their engagement. Thus, by presenting the Yugoslav conflicts in the early 1990 s as merely the reoccurrence of an outbreak of ancient hatreds in the Balkans, the Western media were able to imply that all the sides in the combat were equally to blame. This implied that any involvement in the crisis would be misguided. Sadkovich's study of the US media's treatment of the earlier phases of the Yugoslav conflicts offers an apt portrayal of such methods being employed. ${ }^{10}$ This, he claims, was partially due to a need to justify the non-interventionist stance of the Bush government, but it was also due to other factors such as hostility towards the creation of smaller states amongst certain neo-imperialistic elements of the US media. Wheeler 
notes that Western journalism helped create an impression that 'the peoples of the Balkans inhabit a realm of preternatural barbarism, ludicrous ambitions, congenital perfidy, inveterate cruelty and unfathomable complexity with which the civilized world is ill advised to cope." Such careless and tardy stereotyping of the situation in the former Yugoslavia helped to convince the Western public that any intervention would be pointless and foolhardy, hence legitimising their governments' laissez-faire attitude towards the situation.

As happened in the case of the Yugoslav conflict, warring factions can also use the media for propaganda purposes, either in the lead up to, or during, a conflict. This can be achieved either by demonising the opposing side or by portraying their side in categories that are both accessible and attractive to their own citizenry. In the lead up to the conflicts in Croatia and Bosnia, the Serbian media played a role in driving the ethnic Serbs in these republics to demand secession, by convincing them that their identity and even their lives would come under threat with the establishment of the two republics as independent states. The Serbs in Eastern Bosnia were urged to take part in the conflict because of warning of alleged Muslim plans to launch a jihad against them. Such allegations were not true, especially as the Bosnian Muslims were at the time mainly secular in outlook. Unscrupulous Serb leaders, both in Belgrade and Pale, as well as the machinations of the Serb media, engineered these warnings of a jihad. Media influence was evidenced most strikingly in the broadcasts of Radio Television Belgrade, which constantly warned of the dangers of a fundamentalist jihad in the months leading up to the outbreak of hostilities in Bosnia. These dire warnings had the effect of creating, as Malcolm terms it, a 'psychology of terror' amongst the ordinary Bosnian Serb population, driving them to believe that the threats were real and that they would have to defend themselves against their Muslim neighbours. ${ }^{12}$ During the recent bombardment of Yugoslavia, the influence of Serbian propaganda in promoting its country's war effort was perceived by the NATO forces to be of sufficient magnitude to warrant aerial attacks on the television station in Belgrade and other elements of the media apparatus. As a corollary to this, the inability or unwillingness of the Serb authorities to launch a strong media offensive on international audiences in the 1990s was to be contrasted with the Croats and Bosnian Muslims who both placed great stress on public relations with the rest of the world. This ensured that over time the sympathy of the West would rest with the opponents of the Serbs: a factor that would have a great bearing on the eventual outcome of the conflicts. 


\section{The Nation State and Nationalism}

The nation state was the prime unit of territorial organisation in the era of modernity, emerging in Europe out of the political fragmentation of the feudal period. However, in the postmodern era the role of the nation state is declining with the ever-increasing impact of globalisation. In terms of politics, its role is being eroded by a complex combination of centrifugal and centripetal forces. For example, greater transnational political union in Western Europe is occurring in tandem with instances of political fragmentation within Europe, unparallelled since the end of World War 1. Such political fragmentation has impacted mainly on Eastern Europe, but also to a lesser degree on parts of Western Europe such as Scotland, Northern Ireland, northern Italy, Catalonia and the Basque region. Adding further confusion to this picture is the fact that these two processes can sometimes intersect. For instance, Slovenia and Estonia, which were formerly constituent republics of the former Yugoslavia and the former Soviet Union respectively, are expected to be in the next wave of countries joining the European Union.

A key aspect of postmodern society is the replacement of the nation state by economic blocks such as the EU and NAFTA in terms of its role of initiating effective economic interventions. ${ }^{13}$ Processes associated with globalisation, such as the growing impact of global financial institutions, like the IMF, and multinational corporations on different national economies, are proving a key mechanism in which the role of the nation state, as regards its control over macroeconomic policies, is being denuded. Commenting on the role of transnational corporations, Baum claims that they have taken the control over the distribution of power and wealth that national governments once had. ${ }^{14}$ Owing to their lack of concern for social justice, this has resulted in an increasing gap between rich and poor, a growth in unemployment levels and an individualist culture that is marked by a lack of social solidarity. This in turn, it could be argued, has resulted in the emergence or strengthening of national separatist movements in parts of Europe and North America, which had up to the late 1970s appeared immune to such pressures. Often these arose in response to the deprivation suffered as a result of the adverse impact of multinational corporations and neo-liberal economic policies such as Thatcherism or Reaganomics. A similar scenario has developed related to the structural adjustment policies unleashed by the IMF and World Bank on states, mainly in the Third World, that were unable to pay debts owed to these institutions in the wake of the global financial crises of the 1970s and 1980s. These policies involved economic austerity programmes, which eschewed social security and employment creation in favour of economic growth. They also placed great 
emphasis on free trade and promoted export-oriented production at the expense of domestic production. For the Yugoslav economy, the intervention of the IMF was to result in austerity programmes that would mean low or negative GDP growth rates from 1980 onwards, severe commodity shortages and hyperinflation, thus creating the conditions for the growth of nationalist violence in the 1980s.

With the growing invasion of global media products, mainly American in origin, into different parts of the world, there is a fear that the legitimacy of nation states will be further imperilled by this as a form of cultural imperialism. Some commentators view this form of cultural globalisation as a form of 'Americanisation', while Smith refers to it as a process of 'electronic internationalisation'. ${ }^{15}$ It could be argued that this process could prove a means of evoking a displacement of nationhood and national cultures through the import of cultural, entertainment and artistic commodities. Hence, it is hardly surprising that Smith envisages the key role of the nation state today as defending its cultural homogeneity in the face of the 'transborder data-flows' that are imperilling this. He claims that the state has already yielded its ability to determine its economic, political and military destiny to various supranational agencies, although he does warn against assigning too great a weight to this process. ${ }^{16}$ Such cultural globalisation can have the effect of further strengthening the core regions' political and economic dominance.

In his consideration of both postmodernity and globalisation, Harvey notes how the associated concept of time-space compression should alert one to potential dangers associated with geopolitics and nationalist conflict. $\mathrm{He}$ believes mental maps and, as a result, political thinking have not changed sufficiently in response to the processes of time-space compression and flexible capitalism. He argues that people's imaginations have not altered sufficiently to cope with the bewildering pace of time-space compression, evoking in turn a sense of uncertainty and unease. The decline of the nation state, in terms of its control over fiscal and monetary policy, has not been linked with a necessary internationalisation of politics, as Harvey also notes. In such a vacuum, he argues, these processes can be seen to be encouraging the growth of localism and nationalism. This is due to the need for security that an attachment to place can offer in a time of great insecurity, resulting from the changes linked to postmodern and globalising processes. Thus Harvey here offers an interesting theory as to why the decline in the role of the nation state, due to supranational factors and agencies, can occur at the same time as nationalism and political fragmentation is reasserting itself in different parts of the globe. ${ }^{17}$ Hence postmodernity, in this context, offers a perplexing dynamic between cohesion and disintegration, yet another of the paradoxes associated with the postmodern world. 


\section{Theories Regarding Postmodern Conflict and Their Relevance for the Former Yugoslavia}

There are a number of theories as to why conflicts can and will erupt in postmodern society. However, the main strands in debates on this issue seem to be summarised in two contesting positions: one is that such conflicts are linked to economic or structural factors and the other perceives all conflicts as clashes between different cultural groups. Both these positions have considerable relevance in an attempt to understand the confusing myriad causes of the conflicts that accompanied the disintegration of Yugoslavia in the 1990s. The remainder of this paper will consider the usefulness of these viewpoints in the context of the wars in the former Yugoslavia. Before doing so, it must be noted that other possible reasons for engaging in conflict in postmodern times has recently come to the fore. One of these involves engaging in hostilities for humanitarian purposes. While the intervention of US troops in Somalia in 1992 could be portrayed in such a light, it is perhaps the recent NATO action against Yugoslavia, in response to the ethnic cleansing of Albanians within Kosovo by Serb forces, that is the most notable example of this. Opponents of such actions often claim that the real reason for humanitarian based conflict may lie instead in a desire by the perpetrators of such action to extend spheres of influence into new regions. The NATO action in Kosovo could be seen in such a light and was condemned by the Russian Federation which perceived it as an unwarranted transgression into the territory of a country it believed to be within the Russian sphere of influence. Another interpretation would be to claim that postmodern conflicts emerge as a means of justifying the enormous amounts of government military expenditure, in order to also mollify the powerful arm manufacturing lobbies within countries such as the USA.

\section{Economic Aspects of National Based Conflict}

Of all the factors to be considered in studies of the causes of different conflicts, it is usually economics that proves to hold most sway. Many wars have been fought for reasons such as creating spheres of economic interest, territorial acquisition, and controlling regions that are rich in resources. In many cases, such conflicts may be couched in terms of factors such as ideology, religion, and humanitarianism to ensure the support of the relevant citizenry for the war effort. Such a scenario has been seen in the case of some of the Yugoslav conflicts. Part of the rationale behind Serb attacks on the regions of Eastern Slavonia and Kosovo lay in the economic value of these areas: Eastern Slavonia for its rich agricultural land and oil; northern 
Kosovo for its valuable lead, zinc and silver mines. These conflicts were then presented as being solely related to the protection of ethnic Serbs in eastern Croatia ${ }^{18}$ or the retention of the 'cradle of Serb civilisation' for her people.

A closer study of the economic aspects of globalisation is required in order to develop an economic theory of postmodern conflict. It is clear that competitive globalisation, by its pursuance of jobless growth, is creating insecurities worldwide, as well as increasing economic inequalities that are marginalising individuals, communities and indeed whole regions such as Eastern Europe and the Third World. This helps create conditions in which resentment, alienation and violent conflict grows. Growing material inequities and increasing impoverishment resulting from processes of competitive globalisation can spark off protests against governments. Geller and Singer note a significant linkage between domestic disturbances and engagements in foreign conflict. ${ }^{19}$ Underpinning these views were the antiMilosević demonstrations in Belgrade in the lead up to both the earlier conflicts in Slovenia, Croatia and Bosnia, as well as the present phase of the conflict in Kosovo.

In such a vein, Houtart employs an economic framework, based on observations regarding inequities caused by globalising processes, to theorise about the basis from which future postmodern conflicts - will develop. ${ }^{20} \mathrm{He}$ holds that the underlying cause of most future conflicts will be rooted in such inequities. Peripheralisation caused by the globalisation of economic systems, he holds, will revive amongst those marginalised by this process forms of conflict which appear to be traditional in nature, but which are actually linked to the low priority the postmodern economic system places on issues of social justice. Indeed, with increased globalisation, most of the economies in the former Yugoslavia - with the notable exception of Slovenia - found themselves becoming more peripheral to the global economy. This factor has undoubtedly had some influence on the outbreak of hostilities in that region in the 1990s, while the economic dislocations caused by the wars there have furthered the region's peripheralisation. Hence, it appears that the humanitarian crises and economic devastation associated with war could be prevented if international agencies such as the $\mathrm{UN}$ and IMF acted in peripheral regions to ameliorate economic conditions that may encourage the outbreak of hostilities. This would demand that the World Bank and IMF, even when it may be against their own interests, help to create structures where poor people worldwide are not 'treated as the collateral damage of advanced capitalism' and hence do not have to resort to violence. ${ }^{21}$

Recent debate regarding the 'pacifying' of the Balkan region has formed around such an idea; that of a 'Marshall Plan' for all the Balkan countries. 
However one may have cause to doubt whether such a course of action will be pursued, especially in the wake of the recent Balkan Stability Pact summit. Held in Sarajevo on 30 July 1999, it has been considered to have been showy, ill-prepared and premature, especially considering the exclusion of Serbia, whose stability is key to long term hopes for peace in the region. ${ }^{22}$ Most commentators claim that it was of little value other than as a symbolic gesture, and amounted to nothing more than providing the assembled world leaders with an expensive and showy photo opportunity. This led a recent editorial in The Independent on Sunday newspaper to argue that 'politicians presiding over the ruined Balkans need to be able to break free of the pathological desire to shine on television screens at home'. ${ }^{23}$ This, of course, furthers the argument, touched on earlier in this paper, that style and sound-bites are of more concern to postmodern politicians than are the less media-friendly qualities of effective policy making and long-term planning. Further causes for concern were the refusal of governments to make long term commitments to the rebuilding of the region, as well as the re-emergence of 'tied aid' as part of the relief pledged by certain governments. In the light of this, one must question whether there is sufficient motivation amongst Western governments to make a significant financial commitment to the region, especially as the political capital accruing to the 'successful' NATO military operation in Kosovo has dwindled in the months subsequent to the cessation of hostilities there. As has been the case with other troubled parts of the world, once the glare of the media is drawn away from Kosovo and the rest of the Balkans and once its worth as a means of bolstering public opinion has faded, it is likely that the region will be forgotten by media conscious Western governments.

Perhaps the key impact that the economic forces of globalisation had in causing the disintegration of Yugoslavia, and hence the resulting conflicts, rested with the economic austerity programmes imposed on the country by the IMF in the early $1980 \mathrm{~s}$. Such programmes have already been mentioned. This action by the IMF was due to the Yugoslav state's inability to service its debt in the wake of the global economic crises of the 1970s. As in many parts of the Third World, this IMF intervention was to result in dire economic problems for the people of Yugoslavia, providing a cautionary tale against the imposition of the structures of Western capitalism on economies that had worked according to other principles or ideologies. ${ }^{24}$ The result of enduring these restructuring programmes was to mean very low, or even at times negative, GDP growth rates in Yugoslavia from 1980 onwards, as well as severe commodity shortages. Even in times of peace, there were regular episodes of hyperinflation that reached a height of over 1,200 per cent in 1989. There were also drastic increases in the state's unemployment rate, which reached a height of over 17 per cent in 1987. 
Considerable spatial variations in the unemployment rate existed within Yugoslavia, with higher rates being recorded in some republics and provinces. During the 1980 s the rate averaged at over 20 per cent in Serbia, nearly 30 per cent in Bosnia, Macedonia and Montenegro and nearly 60 per cent in Kosovo. The two north-western republics fared much better, to the extent that Croatia's rate stayed below 10 per cent for most of the 1980 s while there was full employment in Slovenia. Within the different republics there were also spatial variations in the rate; for instance the Serb dominated areas of the Krajina were to suffer much higher levels of unemployment and economic depression than did the rest of Croatia. Youth unemployment was also a factor: by 1985 the number of people under the age of 25 unemployed had reached a height of 38.7 per cent. ${ }^{25}$ These factors describe the economic malaise that was to create conditions of alienation and social dislocation in parts of Yugoslavia, as well as growing resentment against forms of ethnic bias in job allocation, which would combine to create an atmosphere in which the likelihood of violent conflict would fester.

Part of the restructuring package was concerned with trying to increase Yugoslavia's foreign currency earnings, so imports were to be reduced and export-oriented production was to be increased relative to domestic production. This had the impact of further favouring the more economically developed republics of Slovenia and Croatia, which had very well developed trade relationships with the Western European economies. This ensured that the Slovene and Croat economies would not suffer the same adverse effects that the other, less well developed regions in the south did, as already seen in the case of unemployment. The further intensification of the sharp economic gradient between these and the southern republics was to lead them to believe that they could prosper to a greater degree as independent entities. ${ }^{26}$ As well as being spared the burden of having to transfer funds to the less developed republics, they felt they would have a better chance, as relatively prosperous independent states, of gaining admission to the European Union than the economically disadvantaged Yugoslav Federation would as an entire entity. Hence, secessionist forces grew in these republics, but most especially in Slovenia, in response to these economic impulses. It is hardly surprising that the resultant rush of Slovenia towards independence was to prove one of the sparks that led to the disintegration of the Yugoslav Federation.

Another major reason for Slovenia and Croatia's desire to secede from the Yugoslav Federation centred on their preference for a decentralised economic system based more on private ownership. This was opposed to the Milosević regime's wish to maintain high levels of state ownership and an economy that was more centralised on Belgrade. In this debate the Federal government and the IMF, who believed a more centralised economy to be a 
prerequisite to ensure the success of their structural adjustment policies, supported Milosević. These concerns fed into a subsequent political debate about the future governance of Yugoslavia in which the northern republics were seen to favour looser links between the different republics, whereas the Federal authorities, the Serbs and the IMF preferred a more centralised political system. This debate, and the failure to resolve it, was to be the factor that eventually resulted in the dissolution of Yugoslavia.

While a link between globalising economic forces and factors leading to the development of the Yugoslav conflicts has been shown, it is important to remember that monetary concerns were not the only factor driving events in the Balkans. In the case of the secessionist republics, in many cases it was not in their best financial interests to pursue such a course. Detachment from the Yugoslav Federation, for instance, meant a breakdown in complex inter-republic trade links that had played a key role in building up the republic economies. Often global economic forces were resisted in the course of the conflicts. Croatia and Slovenia pursued an independent course in 1991 in opposition to the desires of most Western governments and agencies, while Serbia's pursuance of the 'Greater Serbia' project and its military activities in Kosovo came in defiance of economic sanctions. ${ }^{27}$

\section{Cultural Aspects of National Based Conflict}

The former Yugoslavia was the meeting place of three different religious traditions: Islam (Bosnians, Albanians and those in the Sandzak region), Orthodoxy (Serbs, Macedonians and Montenegrins), and Catholicism (Croats, Slovenes and Hungarians). Such a spatial phenomenon takes added weight when one considers the views of Huntington..$^{28}$ In the wake of the conclusion to the ideological conflicts associated with the Cold War, he has argued that conflicts will mainly occur along the fault-lines between the world's different 'civilisations' ${ }^{29}$ Of interest here is his claim that the most significant fault-line in this regard is that separating Protestant or Catholic Western Europe from the Orthodox territories in Eastern Europe. He notes that this line practically separates Slovenia and Croatia from the rest of the former Yugoslavia, although the Western entity does also take in Vojvodina and part of Bosnia-Herzegovina. This historical fault line has bisected Europe for almost 1,500 years, ever since the Roman Empire was partitioned between two emperors, one based in Rome and the other in Constantinople. It is further reinforced by the fact that the Catholic republics were under Hapsburg influence for a number of centuries, whereas the other republics were either controlled or influenced by the Ottoman Empire. Adding further complexity is the fact that these two civilisations share frontiers with an Islamic civilisation: frontiers that also 
pass throughout the territory of the former Yugoslavia. This assumes special relevance considering Huntington's claim that 'Islam has bloody borders' ${ }^{30}$

Adapting Huntington's arguments, one can proceed to argue that this faultline, separating the different cultural and religious traditions of Yugoslavia, is one of an interlinking set of factors that demands attention in a study of the conflicts there. It also offers some insights on aspects of further postmodern conflicts. First of all, given that religion had a key role to play in differentiating between the different civilisations or ethnic groups within Yugoslavia, it appears that religion will remain as a factor to consider in studying causal scenarios for potential political conflict. This may be somewhat surprising in the light of the highly secular nature of postmodernity, but Huntington sees that as a mainly Western phenomenon and talks of an 'unsecularisation of the world' as being a key process affecting the other major global civilisations. ${ }^{31}$ The post-Yugoslav conflict can also be placed in the historical context of the wars that arose, either directly or indirectly, from the schism between the Roman Catholic and Eastern Orthodox traditions in 1054. Related to this, Lieven claims that there is an increasing sense of the Orthodox world becoming culturally and economically peripheral to the core regions of the global economy and civilisation. ${ }^{32} \mathrm{He}$ claims that the recent NATO actions against Serbia, placed in such a context, have bred, and will breed, a sense of alienation towards the more prosperous West in Orthodox countries. Hence the 1999 bombardment of Yugoslavia can be seen as another factor deepening an already wide gap between the Orthodox periphery and the more prosperous Catholic and Protestant parts of Europe..$^{33}$

Huntington's views are also relevant when discussing the extent to which European geopolitics impacted on the Yugoslav conflicts. Of particular relevance in this context are the views of Houtart in relation to the role played by Catholic geopolitics. He reflects that the Vatican and other European Catholic powers desired that there would be a belt of Catholic countries stretching from the Baltic down to the Adriatic, which could hence act as a bulwark against the twin threats of Communism and Orthodoxy ${ }^{34}$ It is in such a context that one can understand why the Vatican, Germany ${ }^{35}$ and Austria so rapidly recognised the independence of Croatia and Slovenia. This also highlights the fact that the different combatants in the Yugoslav conflict were supported mainly by those on the same side of Huntington's fault line. As well as the Catholic support for Croatia and Slovenia, the Serbs attained most sympathy from Orthodox countries such as Russia and Greece. The Bosnian Muslims were supported by the Islamic world, even to the extent of receiving armament supplies from Iran in the latter stages of the Bosnian conflict. ${ }^{36}$ While there is nothing new or especially postmodern about such a process, this shows how traditional aspects of conflicts and alliances can be reinterpreted so as to fit within a postmodern framework. 
One criticism of Huntington's theory, as regards its applicability to a postmodern context, stresses the postmodern respect for otherness, as well as the inherent concern of globalisation to strengthen forms of international interconnectivity. However one has already seen how limited the postmodern notion of respect for ethnic difference can prove to be, especially in the context of growing racism in Europe and the events in Yugoslavia. As regards the claims of globalisation to create greater interconnectedness, Mlinar and Trcek note that often this only really applies to the deepening of cultural links with the global core regions, such as the USA. They also observe a noticeable reduction in the significance of links between neighbouring European cultures at the same time. ${ }^{37}$ In some cases, as with the different nationalities in the former Yugoslavia, if links between neighbouring cultures are such that lines of communications between them are already poor, then the process, pinpointed by Mlinar and Trcek, will create a heightened sense of separateness, misunderstanding and fear between the neighbouring territories, in which the seeds of future conflicts can find fertile soil. Hence the limitations of postmodernity and globalisation in this regard are such as to support Huntington's views.

A more pertinent critique of Huntington, with reference to Yugoslavia, is that in many cases conflicts do not erupt along the dividing lines between the different civilisations. Instead these involve scenarios where pockets of certain ethnic groups find themselves located on 'the wrong side' of this fault line, as with the case of the Krajina Serbs in Croatia. This, however, may be seen as overly pedantic in that one is still considering areas in the near vicinity of Huntington's fault-line. In addition, the conflict between the Serb dominated JNA and the Croats in Eastern Slavonia and the wars between Bosnian and Kosovar Muslims and the Christian Serb and Croat forces would fit his scenario. ${ }^{38}$ Huntington's views are further reinforced by the fact that Macedonia was the only seceding republic to escape military attack from the Serbs, probably because both republics are Orthodox. ${ }^{39}$

Finally, it is interesting to note that there is a close link between Huntington and an economically oriented theory of conflict. In his research on war prone dyads, Bremer notes that interstate conflict is more likely when one state is prosperous and its neighbouring state impoverished than when both states are relatively prosperous. ${ }^{40}$ If this notion is extended to embrace Huntington's line between the different civilisations of Europe, then one will note a relatively prosperous terrain west of the line encompassing key core economies, whereas all areas to the east of the line are peripheral to the global economy. Applying Bremer's theory directly, one would expect this line to be prone to regular outbreaks of conflict, very much in keeping with Huntington's theory. 


\section{Conclusion}

This paper opened with a discussion of the main elements of our postmodern and globalised world. These consisted not only of the recent developments in society, economics and cultural patterns, but also of the philosophical thinking that underpins these changes. As shown, there is little originality in postmodernity, as it mainly involves a number of borrowings from the past that are then reinterpreted in the light of this insertion into a late twentieth century context. The re-emergence of conflicts linked to ethnically based nationalism can be partially understood in such a context. However such activities are very much at variance with the stress in postmodernist thought on the importance of developing an awareness of, an appreciation for, and a growing tolerance towards elements of other cultures. The fact that there are many contradictions inherent in postmodernity could partially explain such a dynamic, as could the claim that much of postmodernism only applies to Western societies. Yet this does not weaken the basis for viewing the events in the former Yugoslavia in postmodern terms.

Two key aspects of these contemporary processes, the media and the declining role of the nation state, were analysed with regard to their importance as regards the growth of nationalist conflict. In some cases, these processes were seen to be applicable to the Yugoslav conflicts. The media were seen to be a key element in a postmodern understanding and awareness of conflicts, albeit one that is susceptible to manipulation by governments and other agencies so as to promote their own interests, even if they are not directly involved in a conflict situation. In discussing the role of the nation state, it was noted however that centripetal, globalising forces are concurrently prompting an antithetical growth of centrifugal forces of regionalism, nationalism and separatism, mainly because of the inequalities, fears and uncertainties that the different processes of globalisation evoke.

The main postmodern theories outlining the most likely causal factors for future conflicts were then outlined and related to the Yugoslav conflicts, so as to see the extent to which these conflicts would fit the pattern of an atypical postmodern conflict. As regards the economic impacts of competitive globalisation, their capacity for evoking widening gaps in monetary well-being between different individuals, regions and states was seen as forming a basis for the growth of insecurities, resentments and eventual hostilities. Applied to the Yugoslav situation, these forces were most evident in the impacts of the economic restructuring programmes of the IMF in the 1980s. The economic malaise and regional inequalities that these policies sparked were seen to be prime causes of the resultant growth of nationalism and secessionism that eventually brought about the 
disintegration of Yugoslavia. However, as the conflicts developed, many of the warring sides were seen to be impervious to globalising economic forces, often promoting their own nationalist programmes when it was not seen to be in their best economic interests.

Huntington's 'fault-line' thesis offers a cultural rationale for an understanding of future conflicts, seeing them as involving wars between different civilisations, which would mainly occur at the cultural 'fault-lines' where these civilisations come in contact. This thesis is seen to have especial applicability in the case of the former Yugoslavia. Here the key fault-line was perceived as being the historic line dividing Western European civilisation from the Orthodox territories of Eastern Europe: a line that divided the republics of Slovenia and Croatia from the other parts of the former Yugoslavia. The former Yugoslavia, moreover, also contained the 'fault-lines' between these entities and Islamic civilisation, adding further to the relevance of Huntington's thesis, as did a number of economic linkages with his theory that were noted. However, this theory is problematic in that often the conflicts in the Balkans involved pockets of ethnic groups located on the 'wrong' side of the fault-lines, such as the Krajina Serbs in Croatia. It is difficult, likewise, to perceive future conflicts in solely cultural terms, as a number of other factors or theories, related to factors such as economics and politics, have to be taken account of. Another difficulty with Huntington's thesis as a theory of postmodern conflict is that it mainly involves a harking back to more traditional causes of conflict, such as religion and ethnicity. However it could be argued that this is another good example of the 'magpie' nature of postmodernity inherent in its tendency to borrow certain elements from the past and re-image them for our time.

There is a considerable congruence between the way conflicts in the former Yugoslavia occurred and the various postmodern theories of conflict, as shown already. As tempting as it might be to portray the Yugoslav wars as a form of an atypical postmodern conflict, it has to be admitted that too many variances have been observed in this paper to view them as totally fitting such a scenario. While the economic and cultural theories outlined in this paper do offer some illumination to a study of the Yugoslav conflicts, it must be argued that there is a need to consider other theories also, such as those related to politics and the roles of certain individuals and elites. What can be claimed is that the utilisation of a postmodern and globalising framework offers an apt and novel means of understanding the causes of Yugoslav conflicts, especially considering their complex nature. Postmodern theories, and discussions related to these, should be further refined so as to offer more insight into the events behind the Yugoslav wars, as well as other recent conflicts. These findings could then be used so as to 
offer a framework to stratagems seeking to prevent seeking to prevent future conflicts, thus ensuring that future debates on the issue of postmodern conflict becomes solely a matter of theory and not of empirical observation.

\section{NOTES}

1. M. Arruda, Globalization and Civil Society: Rethinking Cooperatism in the Context of Active Citizenship (Rio de Janeiro: PACS 1996) p.5.

2. F. Fukuyama, The Great Disruption (London: Profile Books 1999) p.16.

3. F. Fukuyama, 'The End of History', The National Interest, 16 (1989) pp.3-18.

4. M. Glenny, The Rebirth of History: Eastern Europe in the Age of Democracy (2nd edition) (London: Penguin 1993) pp.183-4.

5. As previously defined in: A.P. Kavanagh, 'Economics and Religion as Factors in a Geographical Analysis of a Postmodern Conflict: The Wars in the Former Yugoslavia' (St. Patrick's College, Drumcondra: Paper for Conference of Irish Geographers 1999).

6. D. Kellner, 'Globalization and the Postmodern Turn', in R Axtmann (ed.), Globalization and Europe: Theoretical and Empirical Investigations (London: Pinter 1998) p.32.

7. J.A. Coleman, 'The Sociology of the Media', Concilium 1993/6: Mass Media (Dec. 1993), p.6.

8. Of course, it has been suggested that the Sarajevo bombing acted as the pretext for the NATO actions that their leaders had been waiting for, following the events in Srebrenica.

9. L. Silber and A. Little, The Death of Yugaslavia (revised edition) (London: Penguin 1996) p.252.

10. J.J. Sadkovich, 'The Response of the American media to Balkan Neo-Nationalism', in S.G. Mestrovic, Genocide After Emotion: The Postemotional Balkan War (London: Routledge 1996) pp.113-57.

11. M. Wheeler, 'Not so Black as it's Painted: The Balkan Political Heritage', in F.W. Carter and H.T. Norris (eds.), The Changing Shape of the Balkans (London: UCL Press 1996) p.1.

12. N. Malcolm, Bosnia: A Short History (London: Papermac 1994) p.237.

13. F. Powell and D. Guerin, Civil Society and Social Policy (Dublin: A\&A Farmar 1997) p.83.

14. G. Baum, 'Transcending Frontiers or Invading Territories? Reflections on the Activities of the World Bank', Concilium 1999/2: Frontier Violations (Feb. 1992) pp.29-30.

15. A. Smith, Books to Bytes: Knowledge and Information in the Postmodern Era (London: British Film Institute 1993) pp.4, 77.

16. Ibid. pp.21, 78 .

17. D. Harvey, The Condition of Postmodernity (Oxford: Blackwell 1989).

18. Prior to the outbreak of conflict in 1991, Croats were actually in the majority in the region of Eastern Slavonia as seen in M. Klemencic and C. Schofield, 'Ethnicity, Nationalism and the Changing Status of Eastern Slavonia' (NUI Maynooth: Paper for IGU Political Geography Conference 1998).

19. D.S. Geller and D.J. Singer, Nations at War: A Scientific Study of International Conflict (Cambridge: CUP 1998) pp.51-2.

20. F. Houtart, 'The Cult of Violence in the Name of Religion: A Panorama', Concilium 1997/4: Religion as a Source of Volence? (Sept. 1997) pp.1-9.

21. I. Linden, Liberation Theology: Coming of Age? (London: CIIR 1997) p.51

22. As the editorial in The Independent on Sunday of 1 Aug. 1999 claimed, 'a prosperous Balkans is unthinkable without a prosperous Serbia at its heart'. It argued for the provision of financial assistance to parts of Serbia controlled by opponents of Milosević, so as to offer financial inducements to the rest of Serbia to pursue a more democratic path.

23. Ibid. p. 24 .

24. It also leads one to suspect that the real motivation behind the actions of the IMF was that agency's desire to make the Yugoslav economy more susceptible to the forces of Western capitalism, thus integrating Yugoslavia into the global economy but as a decidedly unequal partner. 
25. S. Woodward, Balkan Tragedy: Chaos and Dissolution after the Cold War (Washington DC: The Brookings Institution 1995) pp.52-7.

26. This was very much the case with Slovenia. Despite suffering certain economic dislocations arising from the loss of its economic relationship with other former Yugoslav republics, such as Serbia, it was to quickly emerge as the most prosperous by far of all the formerly Communist economies. It is poised to gain membership of the EU in the next few years. War damage was to severely retard Croatia's economic potential in the wake of the disintegration of Yugoslavia.

27. Eventually these sanctions ensured that Milosević had turned away from the Greater Serbia ideal by the mid 1990s, thus facilitating the path towards the Dayton Agreement in 1995.

28. S. Huntington, 'The Clash of Civilizations?', Foreign Affairs 72/3 (Summer 1993) pp.22-49.

29. Huntington describes a civilisation as a 'cultural entity', which marks the highest level of belonging and identity that people can possess.

30. Huntington (note 24) p.35.

31. Ibid. p.26.

32. A. Lieven, 'How does NATO get out of this?', The Tablet 24 April 1999, pp.548-9.

33. A similar rationale could also be applied to the relationships between the Islamic world and the West in the light of the continuance of periodic air offensives against Iraq.

34. Houtart (note 19) p.7.

35. While Germans are mainly Lutheran, at the time of the Yugoslav crisis it was the Catholic South Länder of Bavaria and the Rhineland-Palatinate who seemed to have the most political influence on the Kohl government, as his CDU party achieved strong support from these Länder. Added to that there was a large population of Croat guest workers in these Länder.

36. B. O'Shea, Crisis at Bihac: Bosnia's Bloody Battlefield (Bridgend: Sutton Publishing 1998) p.159.

37. Z. Mlinar and F. Trcek, 'Territorial Cultures and Global Impacts', in R. Axtmann (ed.), Globalization and Europe: Theoretical and Empirical Investigations (London: Pinter 1998) p.80.

38. As also would the interconfessional conflicts between Orthodoxy and the Uniate Church in Romania and the Ukraine

39. Such a view runs the risk of ignoring other possible reasons, such as the fact that the Serb population in Macedonia is relatively small. One must also remember that Macedonia declared its independence at a time when the Serbs were preoccupied with conflicts both in Croatia and Bosnia, thus reducing the Serb leaders' desire to fight a costly war on a third front. As well as that, the opposition of Orthodox Greece to Macedonian independence could be seen to be in direct opposition to such a view.

40. S.A. Bremer, 'Dangerous Dyads: Conditions affecting the likelihood of Interstate War 18161965', Journal of Conflict Resolution 36/2 (June 1992) pp.309-41. 